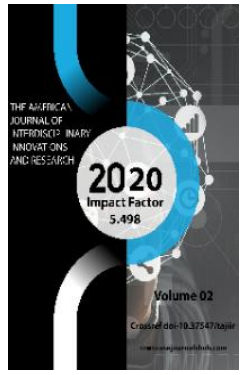

Journal Website: http://usajournalshub.c om/index,php/tajiir

Copyright: Original content from this work may be used under the terms of the creative commons attributes 4.0 licence.

\section{Catalytic Synthesis Of Acetone And Acetaldehyde From Acetylene In Fluoride-Based Catalysts}

\author{
Fayzullaev N.I \\ Samarkand State University, Samarkand, Uzbekistan \\ Akmalaev K.A \\ Satbayev University, Almaty, Kazakhstan \\ Karjavov A \\ Samarkand State University, Samarkand, Uzbekistan \\ Akbarov H.I \\ National University Of Uzbekistan, Uzbekistan \\ E.Qobilov \\ Satbayev University, Almaty, Kazakhstan
}

\title{
ABSTRACT
}

In the study, the catalytic hydration reaction of acetylene in the presence of catalysts based on local raw materials was carried out under stationary conditions in a flow reactor made of stainless steel with a diameter of $25 \mathrm{~mm}$ and a height of $1000 \mathrm{~mm}$. The reaction products were analyzed chromatographically. In the presence of the created fluoride catalyst, the conversion of acetylene is $75-80 \%$, the yield of acetaldehyde is $93 \%$, the yield of acetone is $2.5 \%$. The reason for the high activity of cadmium-zinc-aluminum catalysts is explained by the fact that they form the active center of ox fluorides on the surface of the catalyst. The effect of temperature, volumetric velocity, acetylene: water ratio, etc. on acetaldehyde yield in the presence of the selected catalyst was studied. When the effect of temperature was studied in the range of 300-4400C, an increase in acetylene conversion and a decrease in acetaldehyde selectivity were found with increasing temperature. X-ray studies have established that cadmium-chromo-fluoro-aluminum catalysts have high activity in polymorphic-crystalline state.

\section{KEYWORDS}

Acetylene, hydration, catalyst, acetone, acetaldehyde.

\section{INTRODUCTION}

Currently, acetone is mainly obtained in the industry by the following methods $[1-2,26]$ :

1) Propen directly and indirectly;
2) In the Kumol method. This method consists of 3 steps: 


$$
\begin{gathered}
\mathrm{C}_{6} \mathrm{H}_{6}+\mathrm{CH}_{3} \mathrm{CH}=\mathrm{CH}_{2} \rightarrow \mathrm{C}_{6} \mathrm{H}_{5} \mathrm{CH}\left(\mathrm{CH}_{3}\right)_{2} \mathrm{C}_{6} \mathrm{H}_{5} \mathrm{CH}\left(\mathrm{CH}_{3}\right)_{2}+\mathrm{O}_{2} \rightarrow \\
\mathrm{C}_{6} \mathrm{H}_{5} \mathrm{CH}(\mathrm{OOH})\left(\mathrm{CH}_{3}\right)_{2} \mathrm{C}_{6} \mathrm{H}_{5} \mathrm{CH}(\mathrm{OOH})\left(\mathrm{CH}_{3}\right)_{2} \rightarrow \mathrm{C}_{6} \mathrm{H}_{5} \mathrm{OH}+\left(\mathrm{CH}_{3}\right)_{2} \mathrm{CO}
\end{gathered}
$$

3) Acetone is obtained by oxidizing isopropanol at $450-650 \mathrm{OC}$ in the presence of copper, silver, nickel, platinum catalysts:

$$
2\left(\mathrm{CH}_{3}\right)_{2} \mathrm{CH}-\mathrm{OH}+\mathrm{O}_{2} \rightarrow 2\left(\mathrm{CH}_{3}\right)_{2} \mathrm{CO}+2 \mathrm{H}_{2} \mathrm{O}
$$

Acetaldehyde is obtained by dehydrogenating ethanol, oxidizing ethylene, oxidizing $\mathrm{C}_{3} / \mathrm{C}_{4}$ hydrocarbon fractions, and catalytically hydrating acetylene. Currently, the cheapest and most promising method of obtaining acetone and acetaldehyde for the Republic of Uzbekistan is the catalytic hydration of acetylene. Because today NAVOIAZOT JSC has pyrolysis equipment with a production capacity of 30,000 tons of acetylene per year [3-7].

Today, the global demand for acetone, acetaldehyde, vinyl chloride and vinyl acetates is growing day by day. Therefore, it is important to develop cheap and effective methods of obtaining acetone and acetaldehyde. Currently, effective catalysts with high activity have been obtained for the production of acetylene by catalytic hydro chlorination of vinyl chloride and chloroprene [8-9], acetylation of vinyl acetate [10-14] and hydration of acetone and acetaldehyde [1525].

The reaction for the production of acetaldehyde by catalytic hydration of acetylene was discovered in 1881 by MG Kucherov and has been used in industry for the production of acetaldehyde [1-2]:

$$
\begin{aligned}
& \mathrm{CH} \equiv \mathrm{CH}+\mathrm{H}_{2} \mathrm{O} \stackrel{\mathrm{HgSO}_{4}, \mathrm{HgO}}{\mathrm{H}_{2} \mathrm{SO}_{4}} \mathrm{CH}_{3} \mathrm{CHO}, \\
& \Delta H_{298}^{0}=-150,1 \mathrm{~kJ} / \mathrm{mol}
\end{aligned}
$$

The reaction is strongly exothermic and does not return to $300 \mathrm{oC}$. At temperatures above $300 \mathrm{OC}$, the equilibrium shifts towards the decomposition reaction of acetaldehyde. The following additional reactions take place in the synthesis of acetaldehyde from acetylene: 


$$
\begin{gathered}
2 \mathrm{CH}_{3} \mathrm{CHO} \rightarrow \mathrm{CH}_{3}-\mathrm{CH}=\mathrm{CHCHO}+\mathrm{H}_{2} \mathrm{O} \\
\mathrm{CH}_{3} \mathrm{CHO}+\mathrm{H}_{2} \mathrm{O} \rightarrow \mathrm{CH}_{3} \mathrm{COOH}+2 \mathrm{H}^{+}
\end{gathered}
$$

Oxides and salts of various metals, including phosphates, tungstates, vanadates, molybdates, chromates, have been tested as catalysts for this process. Among all tested catalysts for the catalytic hydration of acetylene to acetaldehyde, the $\mathrm{CdHPO}_{4} \cdot \mathrm{Ca}_{3}\left(\mathrm{PO}_{4}\right)_{2} \quad$ cadmium-calcium phosphate catalyst, developed by Yu.A.Gorin and S.M.Momozon, exhibits high activity and stability [1-16]. This catalyst is active at 350$4000 \mathrm{C}$ and regenerates with air and water vapor at $400-4500 \mathrm{C}$. The process is carried out under conditions of water vapor: acetylene volume ratios 7-10: 1. At this time, the conversion of acetylene is $45-50 \%$, acetaldehyde yield is $89 \%$, croton aldehyde yield is $6-7 \%$. Also in this process acetic acid (0.5-1.0\%), acetone (0.3\%) and various additives are formed. The activity of the catalyst decreases as a result of the formation of resinous products and carbon (coke). Therefore, after 70-100 hours of catalyst operation, the temperature is raised to 400 $4100 \mathrm{C}$. The catalyst is then regenerated. The productivity of the catalyst is 140-216 $\mathrm{kg} /(\mathrm{m} 3 \cdot \mathrm{cat} \cdot \mathrm{h})$ on acetaldehyde. Disadvantages of this catalyst: rapid loss of its activity, low selectivity, low product yield, thermal instability, etc. [1-3]. The aim of the work is to create high-activity catalysts for the catalytic hydration reaction of acetylene on the basis of local raw materials, to study the kinetic laws of the process.

\section{EXPERIIMENTAL PART}

The specific surface area of the sample obtained was calculated by the BET method, the mean size of the mesentery by the BJH method. The spatial composition was studied by diffractometer DRON-3 (CuKa radiation) by $\mathrm{X}$-ray diffraction method. The dispersion properties of the catalyst were examined under a scanning electron microscope (JSM$6510 \mathrm{LV}$ ). The catalytic activity of the obtained sample was studied in the hydration reaction of acetylene. Experiments on the catalytic hydration of acetylene and its derivatives in the vapor phase were carried out under stationary conditions in a stainless steel reactor with a diameter of $25 \mathrm{~mm}$ and a height of $1000 \mathrm{~mm}$. The qualitative and quantitative composition of the reaction products was studied by gas-liquid chromatographic method under the following optimal conditions. Stationary phase $15 \%$ Apiezon- $M$ in Tsvetochrome, column thermostat temperature $1000 \mathrm{C}$, carrier gas nitrogen consumption $40 \mathrm{ml} / \mathrm{min}$, detector - DIP. The duration of the analysis is 12 minutes. Quantitative analysis was performed using the internal standards method. 


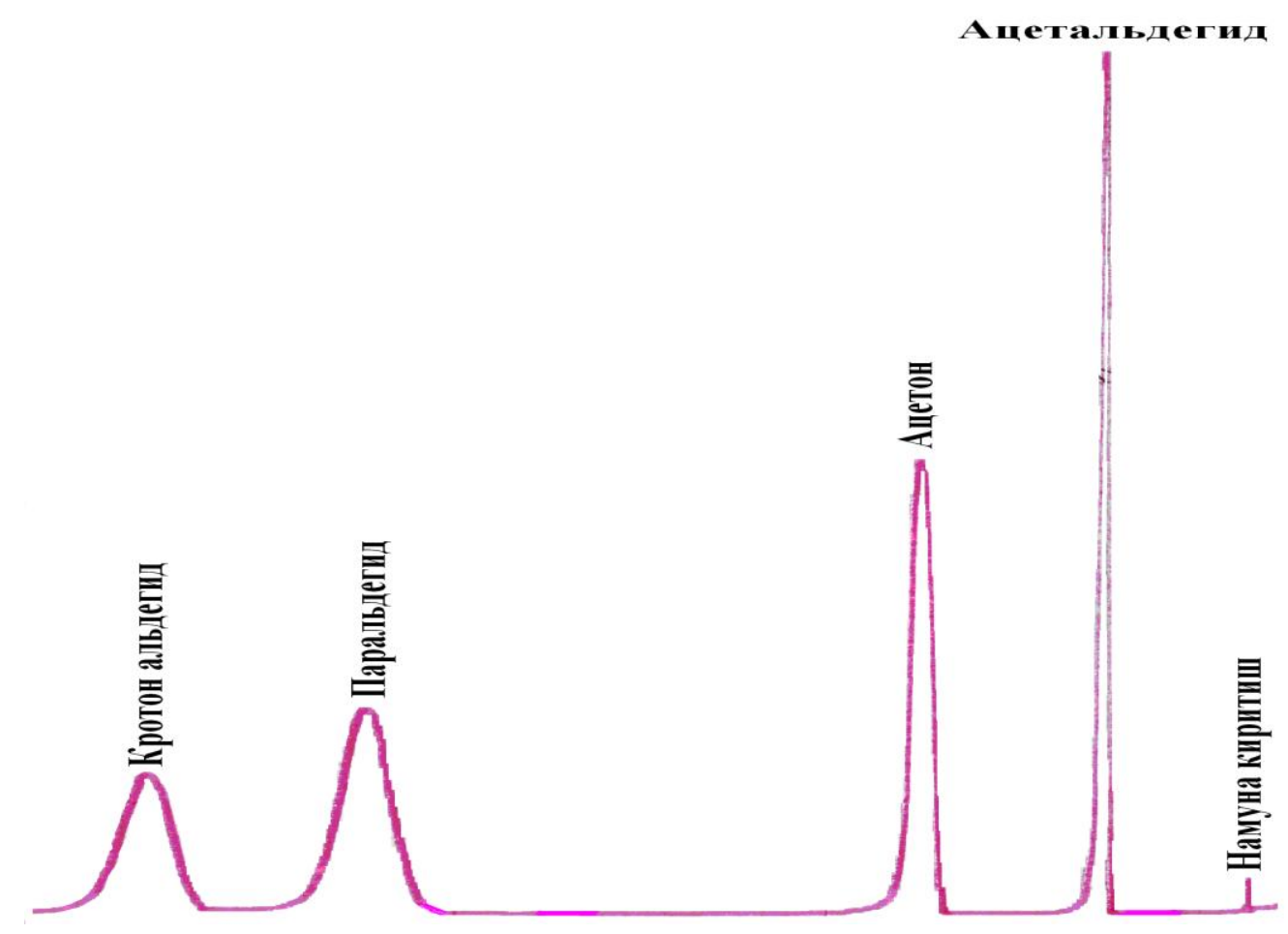

Figure 1. Chromatogram of the products of the catalytic hydration reaction of acetylene

The quantitative composition of the reaction products was determined by the following formula.

$$
C=\frac{K_{i} S_{i}}{\sum_{i=1}^{n} K_{i} S_{i}}
$$

$\mathrm{K}_{\mathrm{i}}$ - the correction factor

$\mathrm{S}_{\mathrm{i}}$-the peak surface area of the determined components, $\mathrm{mm}^{2}$

\section{RESULTS AND DISCUSSION}

Fluoride catalysts with high activity, selectivity and efficiency, high selectivity, thermally stable were selected by the suspension method on the basis of local raw materials. In the presence of the selected catalyst, the conversion of acetylene is $75-80 \%$, the yield of acetaldehyde is $93 \%$, the yield of acetone is 2.5\%. As can be seen from Table 1, the given catalysts ensure high acetylene conversion.
Their stability is 1.5-2.0 times higher than that of cadmium-calcium-phosphate catalyst. The catalyst promoted by up to $5.0 \%$ aluminum fluoride has sufficient activity, mechanical strength and stability. A catalyst containing $10 \%$ to $20 \%$ cadmium fluoride ensures high yields of acetaldehyde. When the reaction is carried out at $300-4200 \mathrm{C}$, the yield of acetaldehyde is $90 \%$ relative to the acetylene that reacts. Additional products include 
acetone, 3- oxybutanal, croton aldehyde, butanal, ethyl acetate, and paraldehyde.

Table 1.

Composition and properties of synthesized cadmium- fluorine-aluminum catalysts.

$(\mathrm{T}=723 \mathrm{~K})$

\begin{tabular}{|l|c|c|c|c|}
\hline $\begin{array}{c}\text { Catalyst components, } \\
\text { mass \% }\end{array}$ & $\begin{array}{c}\text { Specific } \\
\text { surface area, } \\
\mathrm{m}^{2} / \mathrm{g}\end{array}$ & $\begin{array}{c}\text { Operatingtime } \\
\text { before } \\
\text { regeneration, } \\
\text { daily }\end{array}$ & $\begin{array}{c}\text { Productivity, } \\
\mathrm{g} / \mathrm{kg} \text {, cat } \cdot \mathrm{h}\end{array}$ & $\begin{array}{c}\text { Conversion of } \\
\text { acetylene, } \%\end{array}$ \\
\hline $\mathrm{CdF}_{2}-20 ; \mathrm{Al}_{2} \mathrm{O}_{3}-80$ & 220 & 96 & 110 & 95 \\
\hline $\mathrm{CdF}_{2}-15 ; \mathrm{Al}_{2} \mathrm{O}_{3}-85$ & 165 & 120 & 85 & 82 \\
\hline $\begin{array}{l}\mathrm{CdF}_{2}-11,2 ; \mathrm{AlF}_{3}-2,8 \\
\mathrm{Al}_{2} \mathrm{O}_{3}-86\end{array}$ & 135 & 140 & 91 & 90 \\
\hline $\begin{array}{l}\mathrm{CdF}_{2}-15 ; \mathrm{AlF}_{3}-5 \\
\mathrm{Al}_{2} \mathrm{O}_{3}-80\end{array}$ & 151 & 155 & 100 & 92 \\
\hline $\begin{array}{l}\mathrm{CdF}_{2}-10 ; \mathrm{AlF}_{3}-10 \\
\mathrm{Al}_{2} \mathrm{O}_{3}-80\end{array}$ & 183 & 130 & 88 & 94 \\
\hline $\begin{array}{l}\mathrm{CdF}_{2}-5 ; \mathrm{ZFF}_{2}-10 \\
\mathrm{AlF}_{3}-5 ; \mathrm{Al}_{2} \mathrm{O}_{3}-80\end{array}$ & 201 & 160 & 84 & 86 \\
\hline
\end{tabular}

The reason for the high activity of cadmiumzinc-aluminum catalysts is explained by the fact that they form ox fluorides on the surface of the catalyst. Ox fluorides, on the other hand, form active centers on the catalyst surface. Ox fluorides cause the polarization of acetylene and water molecules:

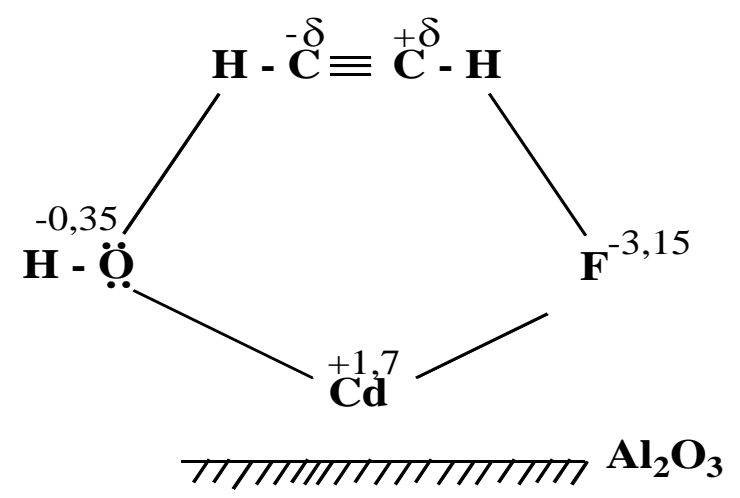

Figure 2. Acetylene on the surface of an oxyfluoride catalyst polarization model of the molecule 
The active particles react to form vinyl alcohol. Vinyl alcohol is isomerizes to acetaldehyde. During the promotion of catalysts prepared by suspension on the basis of cadmium and zinc fluorides and other compounds, the formation of hydroxyfluorides with the following composition: $\mathrm{Cd}(\mathrm{OH}) \mathrm{F}, \mathrm{Zn}(\mathrm{OH}) \mathrm{F}, \mathrm{Al}(\mathrm{OH}) 2 \mathrm{~F}$, $\mathrm{Al}(\mathrm{OH}) \mathrm{F} 2$ was studied by radiographic analysis. the formation of hydrofluorides was found to lead to an increase in catalyst activity. Kinetics of the catalytic hydration reaction of acetylene. The effect of temperature, volumetric velocity, acetylene: water ratio, etc. on acetaldehydrate yield was studied. When the effect of temperature was studied in the range of 300-4400C, an increase in acetylene conversion and a decrease in acetaldehyde selectivity were found with increasing temperature. The study of the effect of temperature on acetaldehyde yield showed that the relationship between reaction reaction temperature and temperature in the range of $360-4400 \mathrm{C}$ is extreme and the yield has a maximum value at 4000 C (Figure 3).

3).

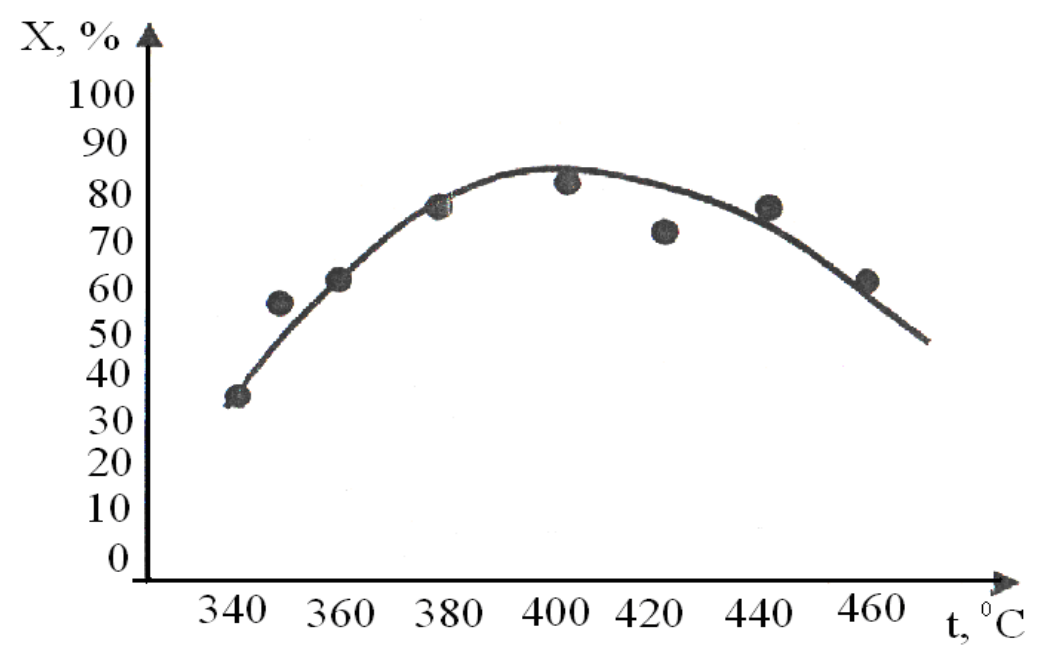

Figure 3. The effect of temperature on acetaldehyde yield

To maintain acetylene conversion at a constant $80-85 \%$, the temperature was increased to $100 \mathrm{C}$ for $15-20 \mathrm{~h}$. The effect of acetylene volume rate on acetaldehyde yield and acetylene conversion was studied in the 50-120 h-1 range. 


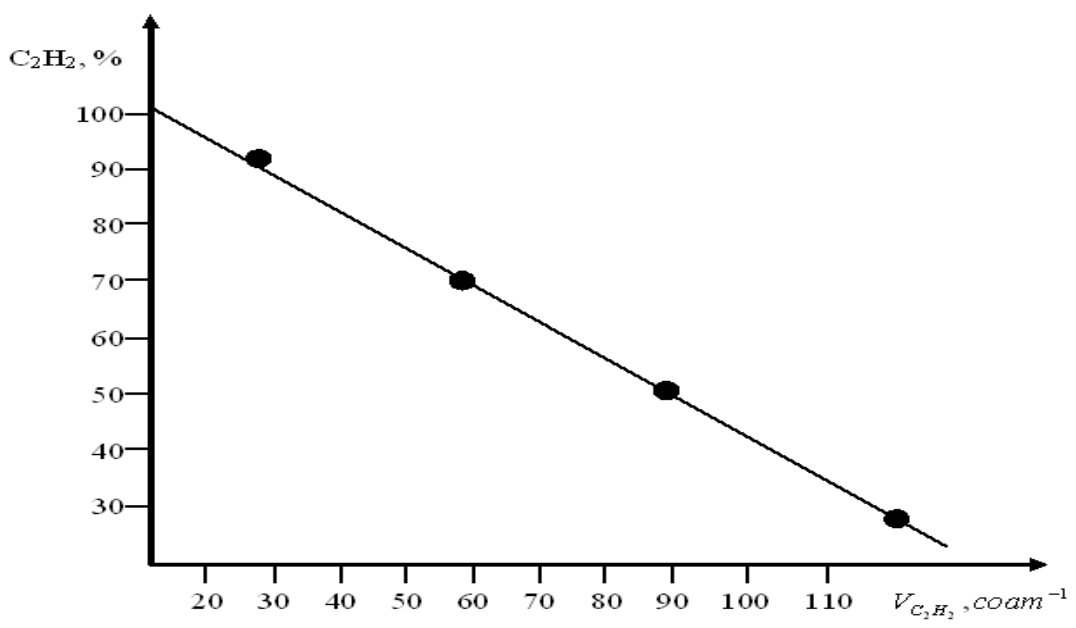

Figure 4. Effect of acetylene volume rate on acetylene conversion.

Acetylene conversion and acetaldehyde yield decreased when the volumetric rate of the acetylene and water vapor mixture was increased from 250 to 500 h-1. The influence of temperature, catalyst size, reactor parameters and catalyst layer heights on the technological parameters of the process was studied.

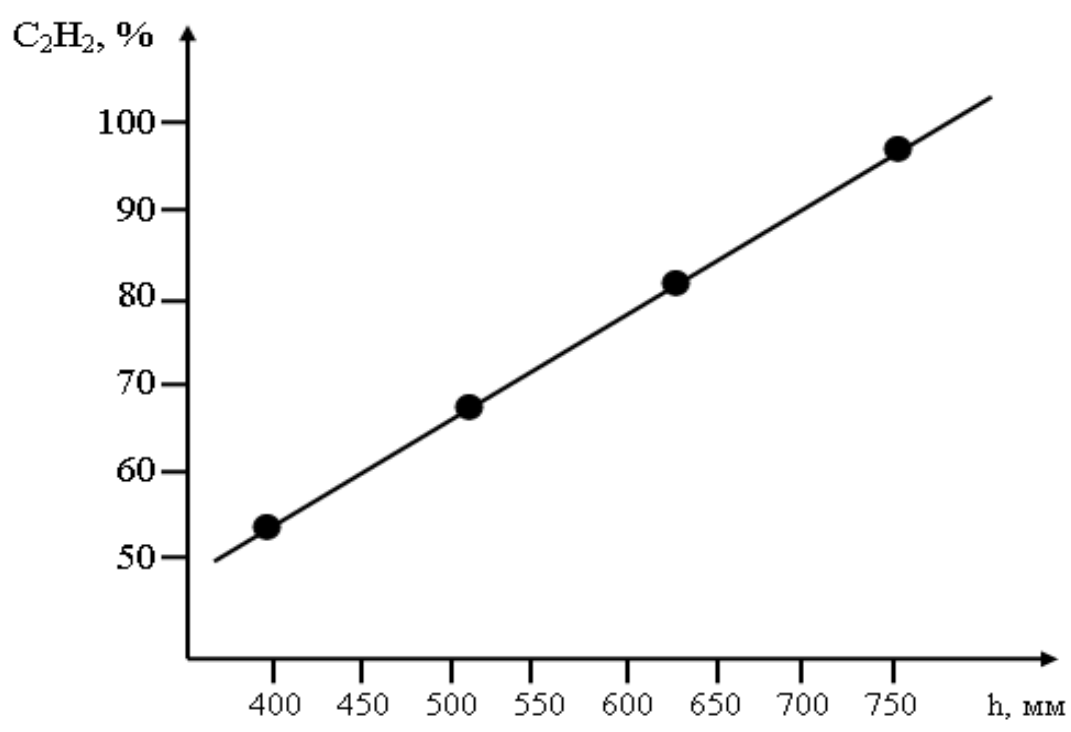

Figure 5. Influence of catalyst layer height on acetylene conversion rate.

The effect of the catalyst layer height on the conversion rate of acetylene is shown in Figure 5:
The ratio of the height of the catalyst layer to the diameter of the reactor is 50-60, and the volumetric velocity of acetylene is 50-60 hours-1. Under these conditions, the catalyst 
№4 (Table 2) operates for 120 hours with constant activity, after 16-24 hours of regeneration, the catalyst fully recovers its activity. Studies have been conducted on the selection of polyfunctional mixed catalysts for the catalytic hydration reactions of acetylene to acetaldehyde and acetone. As a result, a cadmium fluoride and chromium (III) oxide catalyst soaked in aluminum oxide promoted with aluminum fluoride was selected for the acetaldehyde production process. The composition and properties of the synthesized catalysts are given in Table 2 . The hydration reaction of acetylene results in the formation of acetaldehyde or acetone, depending on the composition and nature of the catalyst used under the same conditions. In particular, in the presence of cadmium fluoride catalyst containing $18 \% \mathrm{CdF}_{2}, 2,0 \% \mathrm{AlF}_{3}, 5 \% \mathrm{Cr}_{2} \mathrm{O}_{3}, 75 \%$ $\mathrm{Al}_{2} \mathrm{O}_{3}$ acetylene reacts at $360-4400 \mathrm{C}$ in the ratio: water $=1: 3-1: 5$. The addition of zinc oxide or fluoride (№5 catalysts) to the cadmium-chromium-aluminum catalyst ensures the selectivity of the catalyst and directs the acetylene hydration reaction towards the formation of acetone.

Table 2. Properties and composition of synthesized catalysts

\begin{tabular}{|c|c|c|c|c|c|}
\hline \multirow{2}{*}{$№$} & Content, mass $\%$ & $\begin{array}{c}\text { Specific } \\
\text { surface area, } \\
\mathrm{m}^{2} / \mathrm{g}\end{array}$ & $\begin{array}{c}\text { Processing time } \\
\text { before } \\
\text { regeneration, } \\
\text { hours }\end{array}$ & \multicolumn{2}{|c|}{ Expectedproduct yield, $\%$} \\
\cline { 5 - 6 } 1 & $\begin{array}{c}\mathrm{ZnO}-20 ; \mathrm{AlF}_{3}-3 \\
\mathrm{Al}_{2} \mathrm{O}_{3}-77\end{array}$ & 135 & 72 & 10 & 82 \\
\hline 2 & $\mathrm{CdF}_{2}-20 ; \mathrm{Al}_{2} \mathrm{O}_{3}-80$ & 186 & 96 & 75 & 5 \\
\hline 3 & $\mathrm{CdF}_{2}-18 ; \mathrm{AlF}_{3}-3$ & 210 & 96 & 82 & 3 \\
\hline 4 & $\begin{array}{c}\mathrm{Al}_{2} \mathrm{O}_{3}-79 \\
\mathrm{CdF}_{2}-18 ; \mathrm{AlF}_{3}-2\end{array}$ & 225 & 120 & 83 & 1,5 \\
\hline 5 & $\begin{array}{c}\mathrm{Cr}_{2} \mathrm{O}_{3}-5 ; \mathrm{Al}_{2} \mathrm{O}_{3}-75 \\
\mathrm{ZnO}_{2} \mathrm{O}_{3}-5 ; \mathrm{Al}_{2} \mathrm{O}_{3}-75\end{array}$ & 165 & 120 & 3 & 86 \\
\hline
\end{tabular}

As can be seen from Table 2, the yield of acetone in the presence of № 5 catalyst was $86 \%$, and the pre-regeneration time was 120 hours. This indicates that the most suitable among the selected catalysts are zinc oxide, cadmium fluoride, chromium (III) oxide storage catalysts. Therefore, the effect of temperature on acetone yield in the presence of this catalyst was studied. The yield of acetone formation, the selectivity increases to $698 \mathrm{~K}$. When the temperature exceeds $698 \mathrm{~K}$, the yield of acetone formation and the selectivity of the process decrease due to the conversion to other substances. The production of cadmium-chromium-fluorinealuminum catalyst consists of the following 
main stages: line for acid treatment and activation of expanded clay; mixing and forming line; thermal treatment of the catalyst. For acid treatment and activation is carried out in a reactor equipped with a mechanical stirrer. The calculated amount of expanded clay is sent to the reactor (1) and a certain amount of $10 \%$ sulfuric acid is sent there. The components are stirred for 1 hour, washed, and then the mass is dried at 95 OC for 3 hours (2). At this time, the mill (8) grinds coal, zinc oxides and iron. The mixture of components is sent to the mixer (11) and, with vigorous stirring, $3 / 4$ part of the aqueous solution of the peptizer is added (we use an aqueous solution of extraction phosphoric acid as a peptizer). Stirring continues until a homogeneous mass is obtained.

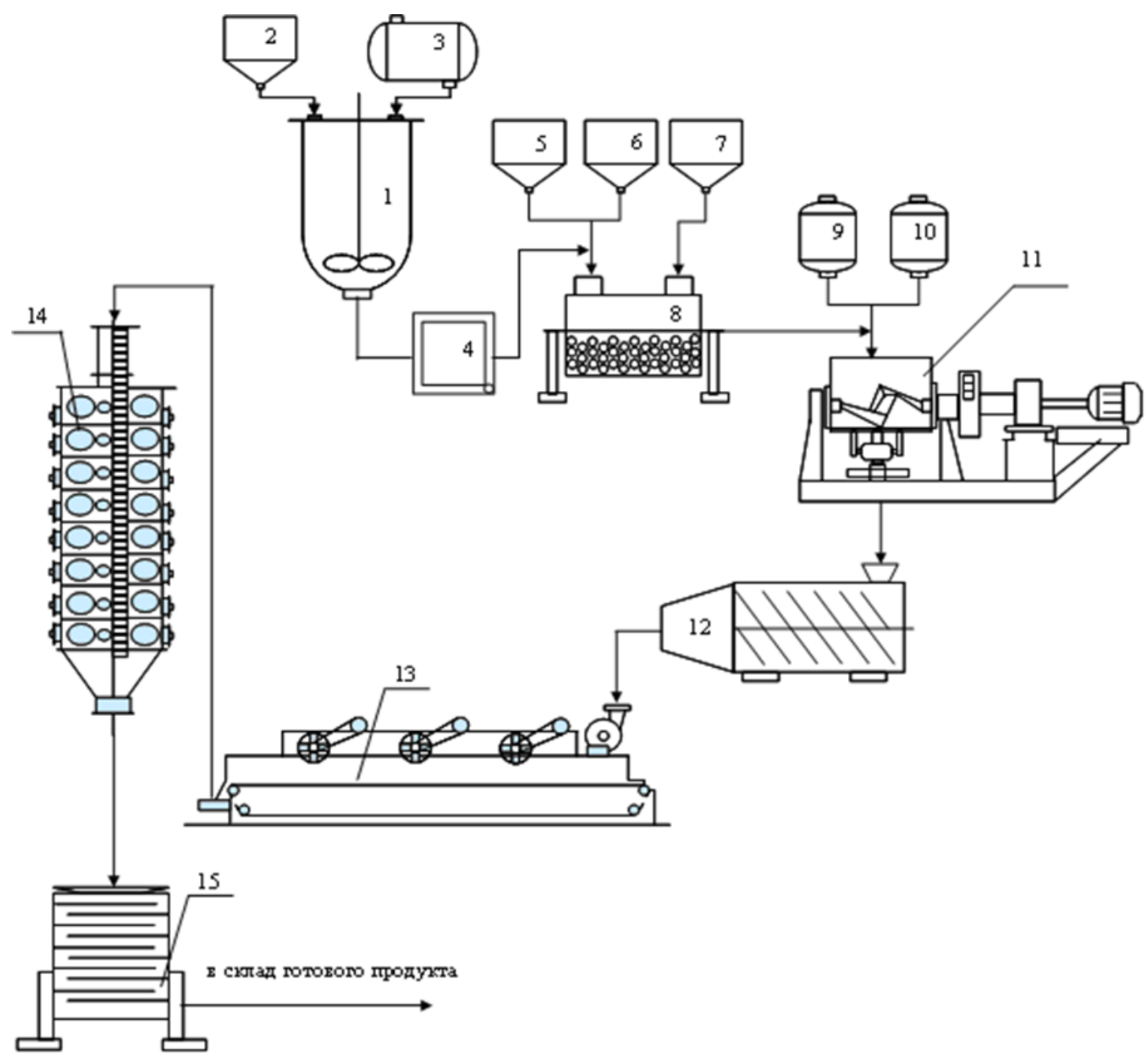

Figure 6. Technological scheme for the production of cadmium- chromium-fluorine- 


\section{ALUMINUM CATALYST}

1 - mixer-activator; 2 - bunker for expanded clay; 3 - tank for $10 \%$ sulfuric acid; 4 - drying cabinet; 5, 6, 7 - containers for iron oxide, zinc and coal; 8 - ball mill; 9, 10 - containers for extraction phosphoric acid and distilled water; 11 - lazy mixer; 12 - molding machine; 13 conveyor dryer; 14 - shaft calcining furnace; 15 - vibrating screens.

Pre-prepared carrier - activated acidic expanded clay after drying is crushed in a mill (8) and sent to the mixer (11) for mixing with the rest of the components, and $1 / 4$ amount of peptizer is added. Stirring continues for 30 40 minutes, after which the mass is sent to the molds (12). For this, a screw molding machine was chosen, which allows to obtain granules with a diameter of $6-8 \mathrm{~mm}$ and a length of 8 -
$10 \mathrm{~mm}$. The granules exiting the granulator contain 20 - 25\% moisture. Drying of the contact mass is carried out in a dryer (13) at 100 ? $50 \mathrm{C}$ for 5 hours.

Heat treatment of the catalyst is carried out in a drum-type furnace (14), while the flue gases and the raw material of the pellets must pass through the furnace in counterflow. The initial temperature of calcination is $2000 \mathrm{C}$, the temperature is raised by $500 \mathrm{C}$ every 30 minutes. up to $450-5000 C$. After calcining, the catalyst is sifted out for discard (14) and sent to the finished product warehouse.

The processing of tree data according to equations (1) - (3) show that the thermal decomposition of the cadmium-chromiumfluoro-aluminum catalyst obeys equation (3).

$$
\begin{aligned}
& \ln \left[\frac{1}{(1-\alpha) 2 / 3} \cdot \frac{d \alpha}{d T}\right]=\ln \frac{k}{g}-\frac{E}{R T} \\
& \ln \left[\frac{1}{\alpha^{n} / 1-2} \cdot \frac{d \alpha}{d T}\right]=\ln \frac{k_{0}}{g}-\frac{E}{R T} \\
& \ln \left[\frac{1}{\alpha(1-\alpha)} \cdot \frac{d \alpha}{d T}\right]=\ln \frac{k_{0}}{g}-\frac{E}{R T}
\end{aligned}
$$

where $\alpha$ - degree of development, calculated on the curved TG woodcutogramme, A - parameter, depending on the mechanism of the reaction speed of the formation of the formation and geometry of the seed; E, R - energy activation and gas.

$\mathrm{X}$-ray studies have established that cadmium-chromo-fluoro-aluminum catalysts have high activity in polymorphic-crystalline state.

\section{CONCLUSION}

In the study, the catalytic hydration reaction of acetylene in the presence of catalysts based on local raw materials was carried out under stationary conditions in a flow reactor made of stainless steel with a diameter of $25 \mathrm{~mm}$ and a height of $1000 \mathrm{~mm}$. The reaction products were analyzed chromatographically. In the presence of the created fluoride catalyst, the conversion of acetylene is $75-80 \%$, the yield of acetaldehyde is $93 \%$, the yield of acetone is $2.5 \%$. The reason for the high activity of cadmium-zinc-aluminum catalysts is explained by the fact that they form the active center of 
ox fluorides on the surface of the catalyst. The effect of temperature, volumetric velocity, acetylene: water ratio, etc. on acetaldehyde yield in the presence of the selected catalyst was studied. When the effect of temperature was studied in the range of $300-4400 C$, an increase in acetylene conversion and a decrease in acetaldehyde selectivity were found with increasing temperature. X-ray studies have established that cadmium-chromo-fluoroaluminum catalysts have high activity in polymorphic-crystalline state.

\section{REFERENCES}

1. Timofeev, V. S., Serafimov, L. A., \& Timoshenko, A.V. (2010). Principles of basic organic and petrochemical synthesis technology. p. 408.

2. Temkin, O. N., Shestakov, G. K., \& Treger, Yu. A. (1991). Acetylene: Chemistry. Reaction mechanism. Technology. Chemistry. p. 416.

3. Omanov, B. S., Fayzullaev, N. I., Musulmonov, N. K., Xatamova, M. S., \& Asrorov, D. A. (2020). Optimization of Vinyl Acetate Synthesis Process. International Journal of Control and Automation, 13(1), 231-238.

4. Faizullaev, N. I., Fozilov, S. F., Ibodullaeva, M. N., \& Khotamov, K. Sh. (2019). Geterogenno-kataliticheskii sintez vinilatsetata iz atsetilena. Nauchnyi aspekt, (1).

5. Fayzullaev, N. I., Karjavov, A. R., \& Yusupova, S. S. (2020). Catalytic Synthesis of Acetone Direct Acetylene Hydration. International Journal of Advanced Science and Technology, 29(05), 4507-4514.

6. Omanov, B. S., Fayzullayev, N. I., \& Xatamova, M. S. (2019). Vinylacetate Production Out of acetylene. International Journal of Advanced
Research in Science, Engineering and Technology, 6(12).

7. Fayzullaev, N. I., Yusupov, D., \& Shirinov, X. Sh., Korotoev, AV., Umirzakov, RR. (2002). Catalytic vaporphase hydration of acetylene and its derivatives. Chemical Industry. N, 7, 1-33.

8. Faizullaev, N. I., Sarimsakova, N. S., \& Bakieva, Kh. A. (2018). Metod polucheniya vinilkhlorida i khloroprena iz atsetilena. Molodoi uchenyi, (24), 273-275.

9. , N. I., Turobzhonov, S. M., \& Omanov, B. Sh. (2018). Vinilatsetat sintezi reaktorini modellashtirish va zharaenni makbullashtirish. I. Karimov nomidagi Toshkent davlat tekhnika universiteti. ToshDTU khabarlari.

10. Fayzullayev, N. I., \& Turobjonov, S. M. (2015). Catalytic Aromatization of Methane. International Journal of Chemical and Physical Science, 4, 27-34.

11. Karjavov, A. R., Fayzullayev, N. I., \& Musulmonov, N. X. (2020). Jointly Catalytic Synthesis of Vinyl Chloride and Chloroprene from Acetylene. International Journal of Control and Automation, 13(4), 55-62.

12. Omanov, B. S., Fayzullayev, N. I., \& Xatamova, M. S. (2020). Catalytic synthesis of acetylene ut of vynil acetate and texture characteristics of catalysts. Asian Journal of Multidimensional Research (AJMR). Special Issue, March, 157-164.

13. Omanov B.Sh., Khatamova M.S., \& Faizullaev N.I. (2020). Tekhnologii proizvodstvennye vinilatsetat. Innovatsionnaya nauka, (3), 10-12.

14. Omanov, B. Sh. U., \& Faizullaev, N. I. (2020). Parametry tekhnologicheskogo rezhima sinteza vinilatsetata. Universum: khimiya i biologiya, (4 (70)). 
15. Fozilov, S. F., Faizullaev, N. I., \& Sodikova, M. M. (2019). Kataliticheskaya parofaznaya gidratatsiya atsetilena. Nauchnyi aspekt, 8(1), 976-979.

16. Sh, S. B. (2018). Rakhmatov Sh. B., Fayzullayev $\mathrm{NI}$ High silicon zeolite preparation from kaolin. Scientific journal of SamSU, 5(109), 106-111.

17. Omanov, B. S., Fayzullaev, N. I., \& Xatamova, M. S. (2020). Vinyl Acetate Production Technology. International Journal of Advanced Science and Technology, 29(3), 4923-4930.

18. Fayzullayev, N., Akmalaiuly, K., \& Karjavov, A. (2020). Catalytic synthesis of a line by acetylene hydration. News of the National Academy of Sciences of the Republic of Kazakhstan, Series chemistry and technology, 2(440), 2330.

19. Fayzullaev, N. I., \& Sh, S. B. (2018). Catalytic aromatization of methane with non-mo-contained catalysts. Austrian Journal of Technical and Natural Sciences, (7-8).

20. Fayzullaev, N. I., \& Shukurov, B. S. (2017). Kinetics and Mechanism of the Reaction of Catalytic Dehydroaromatization of Methane. International Journal of Oil, Gas and Coal Engineering, 5(6), 124.

21. Faizullaev, N. I., Kurbanov, A. M., Shugaepov, N. A., \& Turdiev, M. F.
(2016). Kataliticheskoe atsetilirovanie atsetilena $v$ parovoi fazevprisutstvii nanokatalizatora. Vestnik AING.

22. Fayzullaev, N. I., Jumanazarov, R. B., \& Turabjanov, S. M. (2015). Heterogeneous Catalytic Synthesis of Vinylchloride by Hydrochlorination of Acetylene. IJISET-International Journal of Innovative Science, Engineering \& Technology, 2(9).

23. Faizullaev, N. I., \& Tursunova, N. S. (2018). Poluchenie etilena iz metana $s$ ispol'zovaniem marganets soderzhashchego katalizatora. Khimiya i khimicheskaya tekhnologiya, (1), 24-28.

24. Mukhamadiev, A. N., \& Faizullaev, N. I. (2018). Gazokhromatograficheskoe izuchenie reaktsii kataliticheskogo prevrashcheniya metana $v$ metanol. In XXXV Vserossiiskii simpozium molodykh uchenykh po khimicheskoi kinetike. pp. 110-110.

25. Omanov, B. S., Ibodullayevich, F. N., Anorboevich, E. K., \& Sattorovna, K. M. (2020). Production of vinyl acetate from acetylene. ACADEMICIA: An International Multidisciplinary Research Journal, 10(6), 1031-1038.

26. Fayzullaev, N. I., Akmalaev, K. A., Karjavov, A., Akbarov, H. I., \& Qobilov, E. (2020). Vapor phase catalytic hydratation of acetylene. ACADEMICIA: An International Multidisciplinary Research Journal, 10(7), 88-98. 